\title{
Sustainability of Fashion Apparel Toward Environmental Well-Being and Sustainable Development
}

\author{
Sharifah Shafie, Arasinah Kamis *, Muhamad Firdaus Ramli \\ Email : arasinah@ftv.upsi.edu.my * \\ *: coresponndensing author \\ Universiti Pendidikan Sultan Idris, Tanjung Malim, Perak, Malaysia;
}

Article history

Received Feb 06, 2021

Revised May 01, 2021

Accepted May 31, 2021

Keywords

Eco-friendly Products

Environmental Conservation

Sustainable Consumption

Sustainable Development Goals

Sustainable Education
This paper will look into the agenda of the United Nations (UN) for the planned global, social and environmental progression in Sustainable Development Goals (SDGs), especially goals on the quality of education and responsible consumption and production. The combination of these two goals touched on quality education in the field of fashion and also fostered a responsible attitude among producers and consumers. Hence, educators, designers and manufacturers need to ensure the process and production of ecofriendly products do not harm consumers and nature while reducing the amount of waste. Responsibilities of the manufacturers are in terms of producing and adopting sustainable methods in production of textile and clothing products. Furthermore, consumer attitudes and behaviors are also very influential in utilizing of textile products considering the environmental sustainability aspects. In this study, critical review of relevant literature will be conducted. In the context of education for fashion conservation, it is important to raise awareness on the responsibilities of educators, students, consumers and producers on the importance of conserving the environment for future generations. All parties need to play their role in realizing the aspirations of the SDGs agenda. This aspiration can be achieved in an integrated manner through a combination of sustainable practices, positive attitudes and behaviors.

This is an open access article under the CC-BY-SA license.



\section{Introduction}

United Nations 2030 Agenda on Sustainable Development Goals (SDGs) was planned for global, social and environmental progression, especially goals on the quality of education and responsible and production. The combination of these two goals touched on quality education in the field of fashion while inculcating responsible attitude among producers and consumers. SDG represents the major turning point towards the future potential of mankind. For the first time in history, we have an agreed goal pledged by all UN countries which include various factors that contribute to equitable and sustainable prosperity (Costanza \& Fioramonti, 2016).

SDG encompasses 17 goals representing three areas namely social, economic, and 
environmental. Every goal has a specific target to be achieved over the next nine years, by 2030 . By setting clear goals, SDG is one of the most exciting global initiatives in sustainable development and environmental policy (Biermann et al., 2017). These goals and targets may look too ambitious, but if successfully achieved, nations will reach an improved global development, health and justice (Akenroye et al., 2018). According to Moon et al., (2015) and Saha et al., (2019), the greatest source of pollution in the world stemmed from the fashion industry.

Fashion industry affects the environment mostly by tonnes of water usage, excessive carbon dioxide production and polluting the environment with harmful chemicals (Chen \& Burns, 2006; Dickenbrok \& Martinez, 2018). So, this industry should seriously take this into account by producing eco-friendly clothes at reasonable prices. Hence, the producers need to be responsible for the community and the environment. It is paramount to ensure that the process of clothing production which involved raw materials, processing and production does not affect the environment negatively (Deschamps et al., 2017; Rogers et al., 2018). Environmental pollution occurs through the excessive energy usage in producing clothing, the utilization of non-renewable sources for fiber production, large quantities of water usage, the use of chemicals on renewable sources such as cotton (Žurga et al., 2015). Consumers nowadays are already instill with awareness of environmental pollution and they are well aware of the needs to practice sustainable behavior in the use of clothing (Shim et al., 2018). In addition, there is also a high demand from the consumers for the industry to produce eco-friendly clothing. However, the problem is that consumers demanded these eco-friendly clothing at a low price (Žurga et al., 2015).

Additionally, the continued use of natural resources such as the use of animal fur, cotton, and leather may also result in the extinction of animals (Wai Yee et al., 2016) and might lead to the failure in achieving sustainable development goal (Norum \& Norton, 2017). Such is because sustainability is reached when human and nature come together in a harmonious atmosphere and meeting the needs of the current generation must not affect needs of future generations and the environment (Shen, 2014). Furthermore, the increase in clothing purchases among consumers has also led to the dumping of used clothing, thus, leading to pollution and animal extinction. According to Žurga et al., (2015), the clothing purchases has increased by $1 / 3$ over the last four years. The environment is affected by both the garment manufacturing and usage and also the disposal of garments; which leads to pollution and greenhouse effect (Quinn \& Sinclair, 2016). Clothes disposed at dumping grounds or landfills include artificial and natural fibers. According to Žurga et al. (2015), clothing made of artificial fibers, such as synthetic products, undergo a long process of composting and negatively impact the area of landfill and pollute the soil. Additionally, garments made from natural fibers, although rapidly composed, could still cause pollution and greenhouse effect as the composting process produces methane. Therefore, the purpose of this 
study is to instill a comprehensive awareness for the whole society especially the younger generation about the importance of fashion sustainability in preserving the environment for our well-being.

\section{Method}

This article is a concept paper and only involves a review of the literature. The method used in this study is shown as in Figure 1. Once the researcher has determined the objectives and scope of the study, the next step is to search for relevant prior research articles. The methodology used is to search for articles related to the scope of the study in several search engines such as google scholar and Scopus. Only articles in English and published in the recent 10 years only were selected. Only theories and models underpinning this study were allowed to be more than 10 years back to guarantee the authenticity of the theory or model. We searched the articles from 2010 to 2019 by the following seven keywords that are related to sustainable fashion: "Eco fashion", "Eco friendly material”, "Ethical fashion", "Green Fashion", "Sustainable fashion”, "Sustainability" and "Green Apparel". Once the relevant articles were obtained, the process of determining the suitability of each article was implemented. Only articles with relevant constructs were selected and unrelated ones were removed. The final step is to conduct a meta-analysis of all the relevant articles that have been reviewed.



Figure 1. Method used

Several relevant articles have been collected in this study. Next, a meta-analysis was performed by the researcher to review on the previous studies. Some of the meta-analyzes that have been carried out are shown as in Table 1. Each of the literature reviews listed has also been detailed out its description in the next section. 
Table 1. The meta-analyzes

\begin{tabular}{|c|c|c|}
\hline Author & Research focus & Results \\
\hline Shen, 2014 & $\begin{array}{l}\text { People's concerns on } \\
\text { sustainable fashion }\end{array}$ & $\begin{array}{l}\text { The findings provide industry } \\
\text { insights for practitioners to better } \\
\text { develop and promote sustainable } \\
\text { fashion. }\end{array}$ \\
\hline $\begin{array}{l}\text { Akenroye et } \\
\text { al., } 2018\end{array}$ & $\begin{array}{l}\text { Develop a simple } \\
\text { framework that can help } \\
\text { countries in leveraging } \\
\text { existing budget resources } \\
\text { to guide funding for the } \\
\text { implementation of SDGs. }\end{array}$ & $\begin{array}{l}\text { The framework consists of three core } \\
\text { steps: steering group, gap analysis } \\
\text { and funding roadmap development. } \\
\text { These may possibly help in } \\
\text { mainstreaming the SDGs into the } \\
\text { national budget planning process and } \\
\text { avoiding excessive reliance on } \\
\text { external finance, such as overseas } \\
\text { development aid, which can } \\
\text { undermine the economic } \\
\text { sustainability }\end{array}$ \\
\hline $\begin{array}{l}\text { Žurga et al., } \\
2015\end{array}$ & $\begin{array}{l}\text { Consumer practices } \\
\text { regarding purchase and the } \\
\text { disposal of apparel }\end{array}$ & $\begin{array}{l}\text { Consumers can possess some degree } \\
\text { of environmental consciousness, but } \\
\text { when buying apparel, they usually } \\
\text { don't consider product's impact on } \\
\text { the environment. }\end{array}$ \\
\hline $\begin{array}{l}\text { Arasinah et al., } \\
2018\end{array}$ & $\begin{array}{l}\text { Resent information and } \\
\text { awareness to the society } \\
\text { regarding issues related the } \\
\text { importance of recycling } \\
\text { textile and apparels. }\end{array}$ & $\begin{array}{l}\text { Designers need to be creative and } \\
\text { innovative in re-designing apparels } \\
\text { which are being recycled. The } \\
\text { consumers need to be more positive } \\
\text { and show tendency to buy textile } \\
\text { products and environment-friendly } \\
\text { apparels that are made of used } \\
\text { materials and organic materials } \\
\text { such as bamboo, chicken feather } \\
\text { fiber and vegetable oil. }\end{array}$ \\
\hline $\begin{array}{l}\text { Quinn \& } \\
\text { Sinclair, } 2016\end{array}$ & $\begin{array}{l}\text { Explored the role } \\
\text { transformative learning } \\
\text { plays in the transition to } \\
\text { more sustainable thinking } \\
\text { and actions about clothing } \\
\text { to illuminate instrumental } \\
\text { learning processes and } \\
\text { examine the relationship } \\
\text { between instrumental and } \\
\text { communicative learning. }\end{array}$ & $\begin{array}{l}\text { Most of these participants struggled } \\
\text { to adopt more sustainable clothing } \\
\text { practices as they attempted to } \\
\text { balance their love for clothing with } \\
\text { their passion for sustainability. }\end{array}$ \\
\hline
\end{tabular}

\section{Result and Discussion}

\section{Theory of sustainable development}

Sustainable development' is a concept that has gained global attention since it was introduced by the Bruntland Report entitled 'Our Common Future' in 1987 during the United Nations Conference on Environment and Development. Along with other countries across the globe, Malaysia without exception has shown support and engagement in efforts towards achieving the 
sustainable development (Nor Kalsum, 2016). Shen, (2014) defines sustainability as a development that does not negatively affect the environment for the sake of future generations. According to Deschamps et al., (2017), sustainable practices can be defined as activities to meet human needs but avoiding products and services that have negative impacts on society or the environment at the same time. Consequently, in the context of fashion, sustainability means any form of development and fashion production that will not negatively affect the environment and maintaining it for the next generation. Figure 2 shows the Triple Bottom Line Sustainability Model.

The three main components of the Triple Bottom Line Sustainability Model are economic, social and environment. This model describes activities that involved organizations that have no positive impact on the natural environment and society but benefit the long-term economic and company competitiveness. According to Norizan et al., (2017) if one component is not properly managed, sustainable development will not happen. Most countries are only concern on economic and social, neglecting the environment and natural resources which are greedily exhausted. Hence, the environment component is the main pillar together with economic and social components in establishing sustainable development.

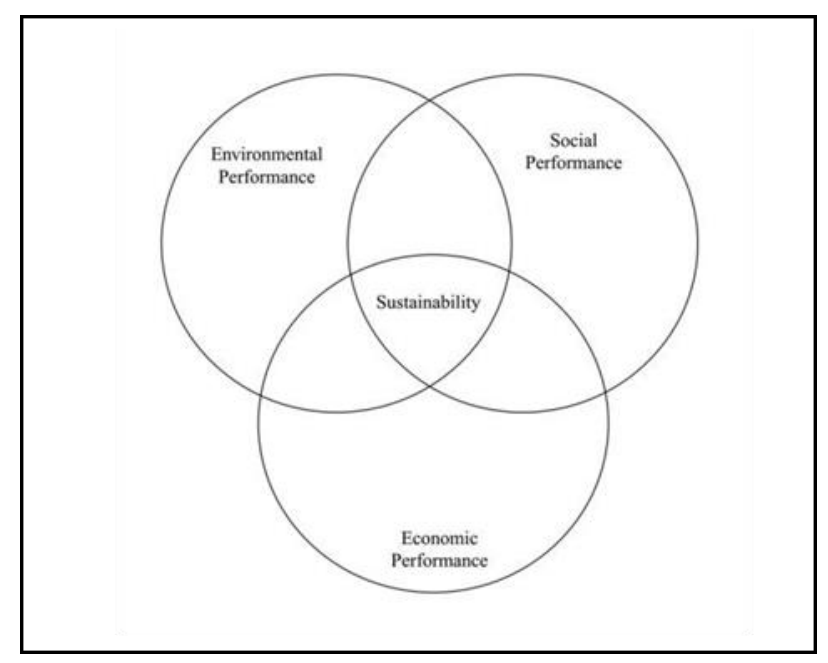

Figure 2. Sustainable model triple bottom line (Carter \& Rogers, 2008)

Additionally, theories and models often used to measure and explain environmental awareness and sustainable development are the earliest model by Ramsey and Rickson in 1976 as shown in Figure 2 on pro-environmental behavior. This model is later known as the KAP Model, abbreviated from the word 'Knowledge-Attitude-Practice/Behavior' (Mahmud \& Siarap, 2013). Among other theories include the Theory of Reasoned Action (TRA), Theory of Planned Behavior (TPB) and the Model of Predictors of Environmental Behavior (PEB). The KAP model refers to three main elements - knowledge, attitude, practice, and behavior (Figure 2). These three elements are the basis for the development of KAP model. Based on this model, with the increase in knowledge of a person will lead to a change of attitude. Changes in attitude may cause changes in 
the person's practice or behavior. Therefore, knowledge is the basis of determination of attitude, intention and behavior. This statement is supported by researchers such as Kaiser et al., (1999) which stated that knowledge is the root of one's attitude and behavior.

Knowledge can be enhanced through exposure to new information through lectures, classes, media, lectures and other academic activities. With regards to attitude, a person's behavior usually depends on his/her attitude built from his/her knowledge. Therefore, changes in attitudes lead to behavioral change. A person's practice or behavior depends on his/her gained knowledge. This modification was done by other researchers who prioritize knowledge as a predictor of attitude and behavior (Flamm, 2006).

Theory of Planned Behavior on Figure 3 was founded by Ajzen and Fishbein in 1975 (Mcneill \& Moore, 2015). This theory was extended by Ajzen and Fishbein from TRA Theory with the addition of controlled behavior components in predicting intentions and behaviors. In this theory, controlled behavior means the extent of an individual has the ability and skill in doing something. Moreover, based on this theory, the important factor that affects one's behavior is intention. The individual intentions are formed from his/her attitudes towards behavior and subjective norms. Attitudes also include behavioral beliefs, behavioral judgment, subjective norms, normative beliefs and motivations. In addition, the TPB is well-known among researchers who want to examine the behavior and tendency of a person on something as well as explaining that behavior is not necessarily influenced by attitudes but can be influenced by the intention to do something (Nor Kalsum, 2016). Furthermore, TPB also applies when measuring individual awareness of the environment and sustainable development.

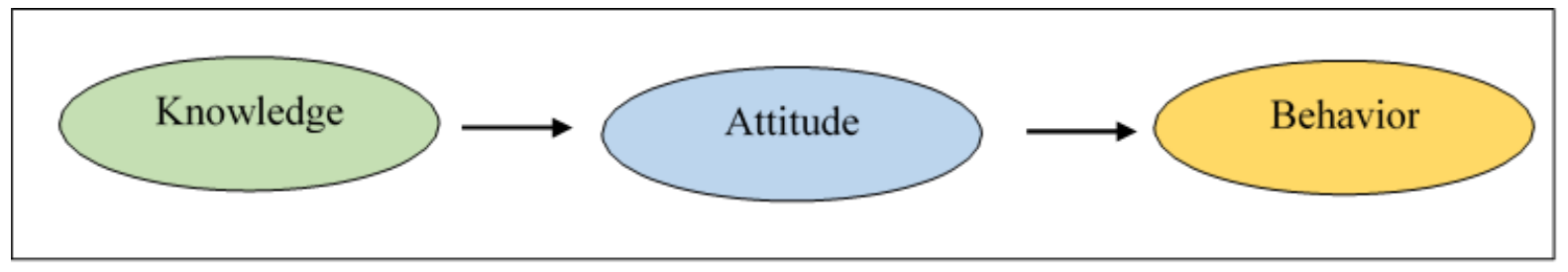

Figure 3. Model KAP Adapted from Ramsey and Rickson 1976

In $\mathrm{TPB}$, attitude refers to the extent of which an individual has a positive or negative attitude towards the behavior to be performed while subjective norms refer to perceptions or beliefs surrounding the individual against the individual in practicing certain behaviors. According to Razzaq et al., (2018) TPB explained that attitude of a pro-environmental individual is formed by having a positive attitude towards the behavior. Firstly, when an individual has a belief that a large number of people have done something which is then regarded as a descriptive social rule. Secondly, one has the confidence that it should be done which is considered a social injunction. Thirdly, one has the belief that they can embrace a new behavior that is considered behavioral behavior that shown on Figure 4. 


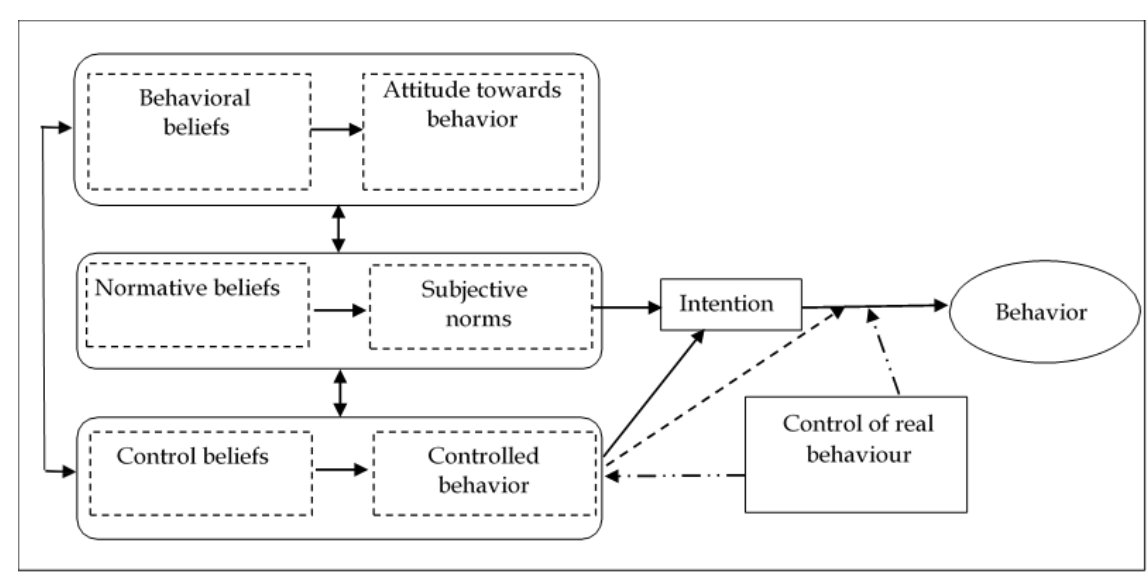

Figure 4. Theory of Planned Behavior-TPB Ajzen (1991)

Thus, in the field of fashion sustainability, the three main domains in KAP Model are referred to as the main model of the degree of awareness namely the knowledge, attitude and behavior of consumers in choosing clothing; assuming that awareness in the sustainable fashion will initiate from knowledge, then attitude and behavior. It is influenced by consumer behavior in deciding to buy and wear clothes, maintain the clothing and eventually disposed them (Carneiro et al., 2016; Arasinah et al., 2018). Sahin et al. (2012) also highlighted that knowledge of environmental issues affects an individual's attitude towards the environment. Based on the theories and models that have been presented, it is found that, to measure a person's behavior in the sustainability of fashion apparel, it includes attitudes, awareness of environmental issues, social norms, and controlled behavior. Subsequently, attitudes will lead to behavior and behavior will encourage the involvement of an individual in learning about the choice of sustainable fashion and the cycle will continue.

\section{The concept of sustainable development}

The Sustainable Development Goals of the United Nations set goals to end poverty, protect the planet from pollution, and ensure prosperity. With 17 goals and 169 targets across social, economic and environment sustainable development (Stafford-Smith et al., 2017). In line with the National Transformation 2050 (TN50) which is the aspiration and development initiative of the country in 2050. One of the aspirations is a healthy environment of sustainable living, environmental preservation, efficiency and safety. In order to achieve SDG, policy makers, scientists and practitioners need to explain how goals and targets including trade and synergies while developing three additional elements - the human well-being matrix and ecosystem, the dynamic model of integrated human and nature systems and innovative ways to build broad general consensus about the desired future (Costanza \& Fioramonti, 2016). The stance or fall of SDG will depend on our ability to contribute towards better governance, more transparent policies, less corrupt administration and more robust legislation (Biermann et al., 2017). According to Norizan et al., (2017) if environmental sustainability is attainable, environmental 
quality will also be achieved especially in terms of health and pollution reduction. In addition, technological innovations are also growing and affecting the cost of production. This will cause decretion of costs while quality of products increases. Recycling efforts and green technology widespread will lead to minimal resource utilization. This will indirectly help conserve the environment in line with the efficiency of the workforce.

\section{Fashion sustainability}

Three key concepts in sustainable development are environmental, economic, and social. These three components are interconnected with one another (Shen, 2014; Sonya et al., 2013; Akenroye et al., 2018). The apparel and textile industry contributed about $\$ 2$ trillion in global revenue. Unfortunately, the industry's tendency to use natural resources and generation of greenhouse gaseous and pollution pose tremendous threats to environmental sustainability (Hiller Connell \& Kozar, 2017). Therefore, it is said that the textile industry is an industry that causes increased waste production that can lead to environmental pollution (Arasinah et al., 2018). Almost every stage in the life cycle of clothing contributes to environmental pollution (Žurga et al., 2015). While environmental issues are somewhat complicated, they are definitely the major issues affecting human life and need to be addressed promptly. A product that considers environmental safety or recyclable can be termed as a good product. That is the reason why textile manufacturers need to take into account the production of fibers, the product manufacturing process and what happens to the textiles during and after the production (Chen \& Burns, 2006; Arasinah et al., 2018). While the designers have to be creative and innovative in redesigning garments that are being recycled (Arasinah et al., 2018).

The concept of sustainable development has also been a major driver around the world to ensure the needs of the people and earth is balanced and indirectly, overcome the issues in environmental pollution. Preserving the environment is vital besides fulfilling the needs not only in the present but also for the next generation. In the context of fashion sustainability, this goal can be achieved in an integrated manner and one of them is through the behavior of disposing of clothing sustainably without affecting the physical environment. In recent years, terminologies such as ethical fashion, eco-fashion, and sustainable fashion has become increasingly popular among fashion designers, clothing retailers, and media (Reeve, 2008). Among the concepts involved in fashion preservation are the need for extensive knowledge on raw material processing, knowledge in clothing manufacturing processes, knowledge of clothing usage involving procurement, use, maintenance, and disposal of clothing (Quinn \& Sinclair, 2016). This fashion sustainibility concept can indirectly determine the new fashion design and the latest trend. Carneiro et al. (2016) argues that the concept of sustainable fashion is difficult to achieve because of its tough challenges. Among the challenges that need to be faced is the fast-moving apparel 
business paradigm, low quality product supplies at competitive prices, and more than 12 clothing collections launched each year.

These challenges are very contrary to the concepts emphasized in achieving sustainable fashion. However, Borman and Sun (2016); Mackiewicz (2012) argued that in the fashion and textile industry there are still some other sub-sectors that can help improve the sustainability of clothing such as the use of fibers that could easily be dispersed and harmless to the environment. In a study conducted by Battaglia et al., (2014) on social responsibility and corporate competitiveness in the small and medium-sized industries in Italy and France, states that audit systems, monitoring systems or formal training are likely to lead to gathering of knowledge and enhancing technical capabilities within the company. This will drive a higher rate of innovation. If more industries are implementing environmental-friendly innovations, more new technologies can be developed in maintaining a sustainable environment. According to Wai Yee et al., (2016), sustainable fashion is not a new concept in the world of research and industry. Since the 1970s, studies on environmental issues involving consumer behavior in the garment wear have been done. However, past researchers emphasized only on consumers' behavior at the acquisition and use of clothing but not on garment disposal. Additionally, quality fashion designs in achieving fashion sustainability should be minimize wastage and damage to nature besides giving positive impacts on consumers and the environment. Therefore, in order to achieve the concept of fashion sustainability, the life cycle of a clothing should sustainable (Carneiro et al., 2016).

Sustainability in fashion also means dressing production that conforms to business justice standards relating to labor conditions, do not negatively affect the environment, and the clothing designs that can be used over a long period of time. In addition, textiles and clothing should also be produced through ethical production systems that minimize adverse environmental impacts and also the use of recycled items (Borman \& Sun, 2016; Fletcher, 2008). Carneiro et al., (2016) argue that among the aspects to be considered for the sustainability of fashion are the certification of raw materials, industrial processing certification, waste management certification during the garment manufacturing process, and the type of product maintenance resilience during use and after use. Sustainability is very important and is a key link to educating consumers about the increasingly tangible environmental issues and enlightening consumers that textiles and clothing also have their own life cycle that must be practiced by every community (Shen, 2014; Borman \& Sun, 2016). Clothing life cycle involves the use of raw materials, processing, distribution to consumers, use, and clothing direction after use within a certain period of time. This cycle is very important in defining the concept of sustainability because it involves the process of a garment produced, the reason consumers buy clothing, and the consumer's disposition of clothing (Carneiro et al., 2016). Additionally, aspects such as good knowledge in the selection and use of 
raw materials, the knowledge of processes involved in the manufacture of textiles and clothing, as well as the knowledge of the life cycle of clothing also illustrates the preservation of the fashion. These aspects can determine the diversity of product designs that can be generated depending on the lifestyle practiced and consumer buying decisions.

Some research thoroughly studied consumers level of knowledge and attitudes on clothing products with features responsible towards the environmental, social and also recyclable. Previous studies have shown that consumers express positive sentiments towards sustainability do not have any knowledge nor social responsibility practices in the apparel industry. In a study conducted by Birtwistle and Moore, (2007), generally, respondents stated that they did not realize the need for recycling of clothing and lack of knowledge about how the clothing was made and the effects to the environment. This is due to lack of awareness and media coverage.

This is supported by a study by Wai Yee et al., (2016) in Malaysia suggesting that authorities organize more consumer education programs to build consumer attitudes towards disposal of clothing to encourage more sustainable disposal. If the impact on the environment from the manufacturing and disposal of these garments is widespread and made widely known, the manufacturer will then accommodate their product and sales strategy accordingly. Respondents also state that they may adjust the way they use clothing and disposition behaviors if they are aware of their environmental impacts (Žurga et al., 2015). Therefore, it is crystal clear here that attitude is an influential factor in the disposal of clothing. In a study conducted by Wai Yee et al., (2016), on philanthropic awareness in the dispositional behavior of young garment consumers in Malaysia also found that when an individual has a positive attitude towards the disposition of clothing, they will behave appropriately and dispose of their undesired clothings in a sustainable way. Therefore, to develop effective clothing disposal behavior, we must first cultivate a positive attitude towards the disposal of clothing. According to a study conducted by Deschamps et al., (2017) about public awareness and the willingness to accept the ethics of sustainable textile products usage in Mexico have found that most respondents understand that the sustainable practice involves minimal waste production especially by the related industries. $85 \%$ of respondents agreed and saw the importance for the industries to be concerned of sustainable practices. A small number of respondents in this study are aware of the importance of environmental sustainability. This is evidenced by $33 \%$ of respondents who have experienced in buying eco-friendly clothes. It shows their concern for the sustainable environment. Most of them felt that the clothes manufacturers are the ones that need to be extra concern on sustainable practices. Most of them felt that their concern for the environment should to be handed over to the large garment manufacturers in the country. This shows that the consumers' knowledge of sustainable fashion is still low. They felt that the industry is more responsible in maintaining 
environmental sustainability compared to their own responsibility as a fashion user.

\section{Clothing life cycle}

Clothing life cycle starts from the stage of raw material processing, distribution or sales stage, usage level, and the direction of clothing after the expiration (Carneiro et al., 2016; Muthu, 2016). Žurga et al., (2015) states that every stage of the clothing cycle could lead to environmental pollution. So, the life cycle of a garment is very important in educating consumers about its influence in attaining fashion sustainability. In addition, sustainable fashion is also influenced by consumer behavior in decisions in buying clothing, clothing usage, clothing maintainance, and clothing disposal (Carneiro et al., 2016). According to Fletcher (2008), clothing life cycle starts with fiber production phase; yarn production, fabric, and product; distribution to user phase; usage phase; and the disposal phase. Laitala, (2014) states that the average lifespan of a clothing lasts only for 5.4 years and some of the reasons for garment disposal are unsuitable size, lack of space for storing, outdated garments, hairy and hatched fabrics, and unfunctional clothing. Wasting of textile can be classified into two groups, namely pre-wasted textile and post-wastage textiles. Pre-wasted textiles are the remnants of the textile, fibers and cotton industries, while post-wastage textiles are textiles that have gone through the consumer market and recycled into other items. According to Shim (1995), the main clothing life cycle starts with acquisition, use and disposal and this cycle has been generally agreed as stated by Birtwistle and Moore, (2007); Jacoby et al., (1977); and Lang et al., (2013) that the element in the sustainable usage of clothing is the process before the purchase, purchase process, and after-purchase process. Laitala, (2014); Quinn and Sinclair, (2016) states that fashion sustainability involves the acquisition of clothing, clothing usage, clothing maintenance, and clothing disposal. According to the United States Cencus Bureau (2013) Report, it is estimated that the glovbal human population is 7.1 billion and increasing at 76 million annually. Due to the increasing population, the global use of textiles and clothing have also increased. It is estimated that the use of world textile and clothing exceeds 30 million tonnes a year and this has serious effects on social and environmental (Chen \& Burns, 2006). Consequently, sustainability is a very important issue in the fashion (Battaglia et al., 2014) and it is the obligation of everyone in the society to be aware of the negative effects on the environment if we do not overcome it together.

\section{Knowledge, attitude and consumer involvement in sustainable fashion}

A study by Moon et al., (2015) on fashion sustainability was conducted online in South Korea. The study aims to assess the pro-environmental attitude and consumer involvement in fashion sustainability. Most consumers admitted to throwing unwanted clothing into the landfill. Most of them are unaware that their actions have caused water pollution and increased global warming. The majority of consumers are also unaware that they have become slaves to fashion 
trends that they have ignored environmental issues with fast fashion trends. Many consumers surveyed do not care whether the products they bought is sustainable or not. Researchers in this study also interviewed fashion professionals in the industry as well as fashion educators. They have argued that there are some obstacles in promoting sustainable fashion, among which are limited knowledge, supply of sustainable raw materials, economic issues and product designs. They mostly think the majority of consumers have limited knowledge of sustainable fashion. With regards to the industry, they noted that the industry faced difficulty in sourcing raw materials for sustainable fashion production and high costs of producing recycled materials. In addition, the price of sustainable clothing is higher compared to normal clothing. The industry is having difficulty in explaining why the price of sustainable fashion product is too high. Problems in designing products also caused difficulty in promoting sustainable fashion products. The industry is tied to the availability of sustainable materials in producing sustainable fashion products. There is also a consumer issue that usually sustainable fashion products appearance are neither trendy nor modern. Consequently, consumers are less interested in sustainable fashion products. Research by Wang et al., (2018) measured the sustainable performance of fashion companies in retail and supply chain based on consumer ratings using the ACSI (American Customer Satisfaction Index). This index will enable us to measure sustainable performance in retail and supply networks based on user ratings and to build constructive models that test whether personal subjective judgments influence the assessment of sustainable behavior. The results of the study have shown that managers of fashion companies should calculate exactly how customers look at every sustainable behavior. Based on index scores, fashion companies can devise their detailed strategies on how to develop sustainability to influence profits. Therefore, fashion companies can devise strategies on how to produce sustainable fashion products as well as attracting fashion users to buy the products.

The study by Razzaq et al., (2018) on the impact of consumer engagement on fashion and pro-environmental attitudes on the use of sustainable clothing has found that consumers who understand the sustainable fashion are more likely to use it. They also want the textile industry to be more sustainable in the process of manufacturing fashion products. High consumer involvement in fashion will lead them to obtain additional information on sustainable clothing fashion. As more and more consumers understand about fashion sustainability, they will be less interested in buying fast clothing that is cheaper and stylish, which is considered as a big contributor of unsustainable fashion. His research also found that a person's pro-environmental attitude was positively related to the use of sustainable fashion. More consumers with attitude towards protecting their natural habitat through their actions, the more they will be involved in sustainable fashion as a way to bring about positive change around the world. In contrast, the 
study conducted by Shim et al., (2018) through a focused group interview to understand the attitude of sustainability and recycling practice at home. A total of 30 respondents were divided into eight groups. The results showed that they make selective purchases of sustainable products in the family and practice garment wash and care that minimize impact on the environment. Recycling is one of the methods in sustainable fashion practices and can reduce waste as the practice of recycling is done at homes with families. From recyclable materials they produced more products. There are respondents in this study who said that the recycling practices also enable them to eliminate their sense of boredom in life, express their own personality, enjoy high emotional satisfaction and make this recycling activity as a hobby. However, this study is difficult to generalize due to the small number of sample studies. Shim et al., (2018) proposes quantitative research for larger target groups.

The study by Geiger and Keller, (2018) is carried out by post to 1, 014 people aged 18 and above in Southern Germany. This study examines the values in sustainable fashion use. The findings show that hedonic values are a relevant factor in explaining sustainable behavior or sustainable fashion use. This value should be taken into account in promoting easy-to-produce clothing to customers who are mostly hedonics. The hedonic value in this study shows a consistent negative relationship to the use of sustainable fashion. Contrarily, Song and Kim, (2018) have studied the factors that predict consumer behavioral intentions to buy ethical or sustainable clothing seen in advertising. The study was conducted in the United States from January 2015 to December 2017 on 829 users. The findings show that four factors that predict consumer intentions to buy green clothing are the perceptions of the quality of clothing, the uniqueness of the clothing, the caring attitude towards the environment. Therefore, effective marketing or advertising strategies should focus on improving consumer perceptions of the quality of clothing. In addition, clothing production also needs to meet the needs of consumers for the uniqueness and quality of sustainable green clothing. The added value in these products will help expand the life cycle and produce better products that reduce the adverse impacts on the environment and society. The intention to buy sustainable clothing is also related to the extent to which consumers have a sense of affection for the environment.

Wiederhold and Martinez, (2018) conducted in-depth interviews with 13 people between August and September 2016. The participants were 5 men and 8 women from different academic backgrounds. His study aims to understand the gap of attitudes and behaviors and explore barriers that prevent consumers from purchasing sustainable clothing. The finding is that the largest barrier is the image. They thought that sustainable clothing is a fashion that is somewhat outdated, too stereotype, made from jut and not fancy. Participants are too worried about their style when they wear sustainable clothing and they want the sustainable fashion produced to suit their tastes. 
The second obstacle is in terms of price. Sustainable clothing is usually more expensive. Price is something that is very important when users want to buy clothes. Sustainable clothing is not an alternative because they have already assumed that the price of sustainable products is high. The participants of this study hoped that sustainable fashion will have the same level of price as other fast fashion. The third obstacle is lack of information and they have little knowledge of sustainable clothing. The next obstacle is transparency. There are some respondents who are doubtful about the trade label used on sustainable clothing. The lack of ethical clothing sources is also a barrier to buying sustainable clothing. Participants are uncertain on where they can buy sustainable clothing because of the lack of supply. The next barrier is usage and inertia. The participants of the study said they liked shopping at the regular stores that they visited because they were already well aware of the quality and products available there. Some participants also feel the impact of their actions on buying sustainable clothing is futile as still many consumers are still buying fashion fast clothing.

The textile and apparel industries have their own shares in contributing to the economic progress of a country. Every day, the number of textile and clothing industries spring up like mushrooms after the rain. The high demand for textiles and clothing is one of the causes of this industry to grow rapidly. Nevertheless, the textile and apparel industry are said to be among the industries that have caused environmental pollution. Based on the relevant literature, the studies analyzing the role that industries and individuals need to play towards Environmental Well-Being and Sustainable Development is summarized in Table 2.

Table 2. Relevant literature

\begin{tabular}{ll}
\hline \multicolumn{1}{c}{ Author } & \multicolumn{1}{c}{ Description } \\
\hline Rahman and & $\begin{array}{l}\text { the textile and apparel industries and also other industries are } \\
\text { trying to apply the concept of sustainability as one of the } \\
\text { priorities in their organizations. }\end{array}$ \\
$\begin{array}{l}\text { Bianchi and } \\
\text { Birtwistle, 2012 }\end{array}$ & $\begin{array}{l}\text { A very fast garment production process will result in an increase } \\
\text { in the purchase of clothes among consumers and the clothes will } \\
\text { only be used in a short period of time and in turn will increase } \\
\text { the rate of disposal of clothes in turn causing environmental } \\
\text { pollution. }\end{array}$ \\
$\begin{array}{l}\text { Shen et al., 2012; } \\
\text { Chan and Wong, }\end{array}$ & $\begin{array}{l}\text { consumers are willing to buy eco-fashion products if clothing } \\
\text { retailers practice the ethics of green practices, produce recyclable } \\
\text { clothing products, and offer recycling services. }\end{array}$ \\
Wai Yee et al., 2016 & $\begin{array}{l}\text { Apart from the uncontrolled production of clothing, human } \\
\text { attitudes in making choices on the disposal of used clothing also } \\
\text { invite environmental pollution as most consumers will ignore } \\
\text { this stage and continue to throw their clothes in landfills without } \\
\text { thinking about the consequences. }\end{array}$ \\
\hline
\end{tabular}




\section{Conclusion}

The textile and apparel industries and also other industries are trying to apply the concept of sustainability as one of the priorities in their organizations (Rahman \& Yadlapalli, 2015). The fashion and textile industry are one of the key industries in the country's economic growth (Rahman \& Yadlapalli, 2015). In addition, awareness of the issues and sustainable behavior in clothing use is also the most important component in achieving environmental sustainability. Furthermore, sustainable behavior must be practiced by garment practitioners such as the industries, consumers, and fashion educators who have an impact on the community to practice sustainable behavior in order to preserve the environment.

The effectiveness of this practice among consumers will be the starting point for SDG policy. Hence, industry and educational institutions need to think of ways to give a comprehensive awareness to the society, especially young generation about the importance of conserving the environment for the well-being of the community. Therefore, a model of clothing preservation should be developed as a guide for practitioners to practice strategic clothing life cycle. Given the seriousness of these issues in causing environmental problems and affecting health, the results of the analysis are expected to create awareness and also shape positive behaviors among young generation in conserving nature and possibly drive consumers to practice the sustainable behavior in the use of clothing.

\section{ACKNOWLEDGEMENT}

The author is grateful to the Universiti Pendidikan Sultan Idris for the funding of this project. This research was support by a grant FRGS from Malaysia Ministry of Education (KPM) (2019-0020106-02). The author would also like to express her appreciation for the constructive comments given by an anonymous reviewer. 


\section{References}

Ajzen, I. (1991). The theory of planned behaviour. Organizational Behavior and Human Decision Processes, vol.50, pp. 179-211.

Akenroye, T. O., Nygård, H. M., \& Eyo, A. (2018). Towards implementation of sustainable development goals (SDG) in developing nations: A useful funding framework. International Area Studies Review, 21(1), 3-8.

Arasinah, K., Farah Najwa, A. P., Suriani, M., Ridzwan, C. R., Baity, B., Rodia, S., \& Emy, B. (2018). Items' Validity and Reliability Using Rasch Measurement Model for Factors that Influence Clothing Disposal Behaviour. Indian Journal of Public Health Research \& Development, 9(11), 1344-1353.

Arasinah, K., Nornazira, S., Rahimah, J., Rodia, S., \& Farah Najwa, A. P. (2018).

Environmentally Sustainable Apparel: Recycle, Repairing and Reuse Apparel. The International Journal of Social Sciences and Humanities Invention, 5(1), 4250-4257.

Ataca, C., Sahin, H., \& Ciraci, S. (2012). Stable, single-layer MX2 transition-metal oxides and dichalcogenides in a honeycomb-like structure. The Journal of Physical Chemistry C, 116(16), 8983-8999.

Battaglia, M., Testa, F., Bianchi, L., Iraldo, F., \& Frey, M. (2014). Corporate social responsibility and competitiveness within SMEs of the fashion industry: Evidence from Italy and France. Sustainability (Switzerland), 6(2), 872-893.

Bianchi, C., \& Birtwistle, G. (2012). Consumer clothing disposal behaviour: a comparative study. International Journal of Consumer Studies, vol. 36, pp. 335- 341.

Biermann, F., Kanie, N., \& Kim, R. E. (2017). ScienceDirect Global governance by goal- setting: the novel approach of the UN Sustainable Development Goals. Current Opinion in Environmental Sustainability, 26-27, 26-31.

Birtwistle, G., \& Moore, C. M. (2007). Fashion clothing - Where does it all end up? International Journal of Retail and Distribution Management, 35(3), 210-216.

Borman,T. \& Sun, D. (2016). Recycled jean: property comparison to standard jean. Journal of Fashion Technology \& Textile Engineering, vol 4(2), pp.2-4

Carter, C. R., \& Rogers, D. S. (2008). A framework of sustainable supply chain management: Moving toward new theory. International Journal of Physical Distribution and Logistics Management, 38(5), 360-387.

Carneiro N., Refosco E., and Soares G. (2016). Contribution to an Efficient Transmission of Information to the Textile Fashion Consumer and the Influence in Sustainable Attitudes. The 90th textile institute world conference. Textiles: inseparable from the human 
environment 25-28 April 2016. Poznan, Poland.

Chan, T.Y., \& Wong, C.W.Y. (2012). The consumption side of sustainable fashion supply chain: understanding fashion consumer eco-fashion consumption decision. Journal Fashion Marketing Management, vol. 16, pp. 193-215.

Chen, H. L., \& Burns, L. D. (2006). Environmental analysis of textile products. Clothing and Textiles Research Journal, 24(3), 248-261.

Costanza, R., \& Fioramonti, L. (2016). The UN Sustainable Development Goals and the dynamics of well- being. Frontiers in Ecology and the Environment, 14(2), 59-59.

Deschamps, T. C., Carnie, B., \& Mao, N. (2017). Public consciousness and willingness to embrace ethical consumption of textile products in Mexico. Textiles and Clothing Sustainability, 2(1), 6.

Dickenbrok, C., \& Martinez, L. F. (2018). Communicating green fashion across different cultures and geographical regions. International Review on Public and Nonprofit Marketing, 15(2), 127-141.

Flamm, M., \& Kaufmann, V. (2006). Operationalising the concept of motility: A qualitative study. Mobilities, 1(2), 167-189.

Fletcher, K., 2008. Sustainable Fashion and Textiles: Design Journeys. London, Earthscan.

Geiger, S. M., \& Keller, J. (2018). Shopping for Clothes and Sensitivity to the Suffering of Others: The Role of Compassion and Values in Sustainable Fashion Consumption. Environment and Behavior, 50(10), 1119-1144.

Hiller Connell, K. Y., \& Kozar, J. M. (2017). Introduction to special issue on sustainability and the triple bottom line within the global clothing and textiles industry. Fashion and Textiles, $4(1), 16$.

Kaiser, F.G., Wolfing, S., \& Fuhrer, U. (1999). Environmental attitude and ecological behavior. Journal of Environmental Psychology, vol.19, pp.1-19

Laitala, K. (2014). Consumers' clothing disposal behaviour - a synthesis of research results. International Journal of Consumer Studies, 38(5), 444-457.

Lang, C., Armstrong, C. M., \& Brannon, L. A. (2013). Drivers of clothing disposal in the US: An exploration of the role of personal attributes and behaviours in frequent disposal. International Journal of Consumer Studies, 37(6), 706-714.

Laporan Brundtaland, WCED. (1987). Our common future. The World Commission on Environment and Development. Oxford University Press, Oxford and New York, pp.400

Mackiewicz-Talarczyk, M. (2012). Handbook of natural fibres. R. Kozłowski (Ed.). Woodhead Pub.. Mcneill, L., \& Moore, R. (2015). Sustainable fashion consumption and the fast fashion conundrum: 
fashionable consumers and attitudes to sustainability in clothing choice. International Journal of Consumer Studies, 39, 212-222. https://doi.org/10.1111/ijcs.12169

Moon, K. K., Lai, C. S., Lam, E. Y., \& Chang, J. M. T. (2015). Popularization of sustainable fashion: barriers and solutions. The Journal of The Textile Institute, 106(9), 939-952.

Muthu, S.S. (2016). Sustainability in the Textile Industry. Textile Science and Clothing Technology. Singapore: Springer Nature Singapore Pte. Ltd. 2017. ISSN 2197-9871

Nor Kalsum, M. I. (2016). Pengetahuan, Sikap dan Tingkah Laku Pelajar UPSI Terhadap PrinsipPrinsip Kampus Lestari Awareness, Attitude and Behaviour of UPSI Students Towards The Principles of a Sustainable Campus. Jurnal Perspektif, 8(1), 29-41.

Norizan, H., Hussin, S., \& Hasimah, A. R. (2017). The Role of Green Technology Application in Context os Sustaining the Environment from Islamic Perspective. E- Jurnal Penyelidikan Dan Inovasi, 4(1), 1-12.

Quinn, L. J., \& Sinclair, A. J. (2016). Undressing Transformative Learning: The Roles of Instrumental and Communicative Learning in the Shift to Clothing Sustainability. Adult Education Quarterly, 66(3), 199-218. https://doi.org/10.1177/0741713616640881

Rahman, S., \& Yadlapalli, A. (2015). Sustainable practices in luxury apparel industry. In Handbook of sustainable luxury textiles and fashion (pp. 187-211). Springer, Singapore.

Ramsey, C.E. \& Rickson, R.E. (1976). Environmental Knowledge and Attitudes. Journal of Environmental Education, vol. 8(1), pp.10-18

Razzaq, A., Ansari, N. Y., Razzaq, Z., \& Awan, H. M. (2018). The Impact of Fashion Involvement and Pro-Environmental Attitude on Sustainable Clothing Consumption: The Moderating Role of Islamic Religiosity. SAGE Open, 8(2), 1-17.

Reeve, J. (2008). Eco-Chic: The Fashion Paradox. Sandy Black, Black Dog Publishing, vol.192, pp., 200. ISBN:9781906155094

Rogers, K., Olah, M., \& Weber, M. (2018). Textile Manager: Design and Development of a Persuasive Game about Sustainable Textile Production. In Conference on Human Factors in Computing Systems - Proceedings (pp. 1-6).

Saha, I., Bhandari, U., \& John Mathew, D. (2019). A Study on Consumer Awareness Towards Green Fashion in India. Research into Design for a Connected World, 134, 483-494.

Shen, B. (2014). Sustainable fashion supply chain: Lessons from H\&M. Sustainability, 6(9), 62366249.

Shen, B.; Wang, Y.; Lo, C.; Shum, M. (2012). The impact of ethical fashion on consumer purchase behavior. Journal Fashion Marketing Management, vol. 16, pp. 234-245.

Shim, S., Kim, J., \& Na, Y. (2018). An exploratory study on up - cycling as the sustainable clothing 
life at home. Fashion and Textiles, 5(14), 1-15.

Song, S. Y., \& Kim, Y. (2018). A Human-Centered Approach to Green Apparel Advertising: Decision Tree Predictive Modeling of Consumer Choice. Sustainability, 10(10), 1-20.

Stafford-Smith, M., Griggs, D., Gaffney, O., Ullah, F., Reyers, B., Kanie, N., ... \& O'Connell, D. (2017). Integration: the key to implementing the Sustainable Development Goals. Sustainability science, 12(6), 911-919.

Su, J., Watchravesringkan, K. T., \& Zhou, J. (2018). Young Consumers' Perceptions of Sustainable Clothing: Empirical Insights from Chinese Post-90s ' College Students. Springer Singapore.

Wai Yee, L., Hassan, S. H., \& Ramayah, T. (2016). Sustainability and Philanthropic Awareness in Clothing Disposal Behavior Among Young Malaysian Consumers. SAGE Open, 6(1).

Wang, H., Liu, H., Jin, S., \& Hoon, K. (2018). Sustainable fashion index model and its implication. Journal of Business Research, (April 2017), 1-8.

Wiederhold, M., \& Martinez, L. F. (2018). Ethical consumer behavior in Germany: The attitudebehavior gap in the green apparel industry. International Journal of Consumer Studies, 42(4), 419-429.

Žurga, Z., Hladnik, A., \& Tavčer, P. F. (2015). Environmentally sustainable apparel acquisition and disposal behaviours among slovenian consumers. Autex Research Journal, 15(4), 243-259. 